\title{
Growth and Photosynthetic Responses of Cuttings of a Hybrid Larch (Larix gmelinii var. japonica x L. kaempferi) to Elevated Ozone and/or Carbon Dioxide
}

\author{
Takayoshi Koike, Qiaozhi Mao, Naoki Inada, Korin Kawaguchi, Yasutomo Hoshika, \\ Kazuhito Kita ${ }^{1)}$ and Makoto Watanabe* \\ Silviculture and Forest Ecological Studies, Hokkaido University, Sapporo 060-8589, Japan \\ ${ }^{1)}$ Hokkaido Forestry Research Institute, Bibai 079-0198, Japan
}

*Corresponding author. Tel: +81-11-706-4180, E-mail: nab0602@for.agr.hokudai.ac.jp

\begin{abstract}
We studied the effects of elevated ozone $\left(\left[\mathrm{O}_{3}\right]\right)$ and $\mathrm{CO}_{2}$ concentrations $\left(\left[\mathrm{CO}_{2}\right]\right)$ on the growth and photosynthesis of the hybrid larch $F_{1}\left(F_{1}\right)$ and on its parents (the Dahurian larch and Japanese larch). $F_{1}$ is a promising species for timber production in northeast Asia. Seedlings of the three species were grown in 16 open top chambers and were exposed to two levels of $\mathrm{O}_{3}$ ( $<10 \mathrm{ppb}$ and $60 \mathrm{ppb}$ for $7 \mathrm{~h}$ per day) in combination with two levels of $\mathrm{CO}_{2}$ (ambient and 600 ppm for daytime) over an entire growing season. Ozone reduced the growth as measured by height and diameter, and reduced the needle dry mass and net photosynthetic rate of $F_{1}$, but had almost no effect on the Dahurian larch or Japanese larch. There was a significant increase in whole-plant dry mass induced by elevated $\left[\mathrm{CO}_{2}\right]$ in $\mathrm{F}_{1}$ but not in the other two species. Photosynthetic acclimation to elevated $\left[\mathrm{CO}_{2}\right]$ was observed in all species. The net photosynthetic rate measured at the growing $\left[\mathrm{CO}_{2}\right]$ (i.e. 380 ppm for ambient treatment and $600 \mathrm{ppm}$ for elevated $\mathrm{CO}_{2}$ treatment) was nevertheless greater in the seedlings of all species grown at elevated $\left[\mathrm{CO}_{2}\right]$. The high $\left[\mathrm{CO}_{2}\right]$ partly compensated for the reduction of stem diameter growth of $\mathrm{F}_{1}$ at high $\left[\mathrm{O}_{3}\right]$; no similar trend was found in the other growth and photosynthetic parameters, or in the other species.
\end{abstract}

Key words: Tropospheric ozone, High $\mathrm{CO}_{2}$, Hybrid larch, Tree growth, Photosynthesis

\section{INTRODUCTION}

In the 1960s and 1970s, Japanese forests and living standards suffered from various types of environmental pollution as a result of rapid economic development after World War II (e.g. Izuta, 2006). These difficulties were overcome with the use of desulfurization equipment and various anti-pollution initiatives. A concern today is the effect of high tropospheric ozone concentration $\left(\left[\mathrm{O}_{3}\right]\right.$ ) on plant production (Izuta, 2006; Omasa et al., 2005). Tropospheric ozone is an air pollutant that is deeply harmful to the growth of tree species (e.g. Kume et al., 2009; Izuta, 2006; Karnosky et al., 2005).

In Japan, $\left[\mathrm{O}_{3}\right]$ has been increasing since the late 1980 s, and global and regional (i.e. Asian) air pollution is believed to be a major reason for the increase (Ohara, 2011). Several researchers suggest that current levels of $\mathrm{O}_{3}$ cause forest decline in several parts of Japan (Kume et al., 2009; Takeda and Aihara, 2007; Yonekura et al., 2001). Moreover, the emission of NOx in East Asia has been increasing, and will continue to increase for the foreseeable future (Ohara, 2011; Ohara et al., 2007), so that $\left[\mathrm{O}_{3}\right]$ in Japan will continue to increase. The atmospheric $\mathrm{CO}_{2}$ concentration $\left(\left[\mathrm{CO}_{2}\right]\right)$ also continues to increase year by year (IPCC, 2007). It is therefore important to predict the combined effects of high $\left[\mathrm{O}_{3}\right]$ and $\left[\mathrm{CO}_{2}\right]$ on the growth and photosynthetic capabilities of representative afforestation species (Matsumura et al., 2005; Paoletti and Grulke, 2005).

In the expectation of high biomass and timber production, the Japanese larch (Larix kaempferi) has been planted in northern Japan from approximately the 1950s, but this larch suffers severely from biotic and abiotic stresses (Koike, 2009; Ryu et al., 2009). To overcome various difficulties, a new hybrid larch $\mathrm{F}_{1}$ has recently been developed (Larix gmelinii var. japonica $\mathrm{x} L$. kaempferi) for afforestation (Kuromaru et al., 2011; Ryu et al., 2009). This hybrid larch $F_{1}$ is characterized by its high resistance to biological stresses (grazing by voles, shoot blight disease, etc.), high rate of growth and high specific gravity of the stem (Kita, 2011). Following the Kyoto protocol (IGBP, 1998), we aim for high $\left[\mathrm{CO}_{2}\right]$ fixation capacity of forest ecosystems to moderate global warming, especially via high $\mathrm{CO}_{2}$ fixa- 
tion and storage capability of the tree species selected.

The newly developed hybrid larch $\mathrm{F}_{1}$ (its nickname is the "clean larch", Kuromaru et al., 2011) is now being planted in many parts of northern Japan. However, no information on its response to elevated $\left[\mathrm{O}_{3}\right]$ with elevated $\left[\mathrm{CO}_{2}\right]$ is yet available (Kuromaru et al., 2011; Ryu et al., 2009).

In the present study, we examined the effect of elevated $\left[\mathrm{O}_{3}\right]$ together with elevated $\left[\mathrm{CO}_{2}\right]$ on the growth and physiology of the hybrid larch $\mathrm{F}_{1}$ and on its parents, the Japanese larch and Dahurian larch. High $\left[\mathrm{CO}_{2}\right]$ usually induces stomatal closure so as to improve the water use efficiency of most C3 plants (Watanabe et al., 2011, 2010; Körner, 2005; Schulze et al., 2005; Koike, 1996). We therefore expect that high $\left[\mathrm{CO}_{2}\right]$ will moderate the harmful effects of $\mathrm{O}_{3}$, because of the resulting reduction in stomatal $\mathrm{O}_{3}$ uptake. Consequently, our hypothesis is that larch growth is not suppressed at high $\left[\mathrm{O}_{3}\right]$ under the future high $\left[\mathrm{CO}_{2}\right]$.

\section{MATERIALS AND METHODS}

\section{1 Plant Materials}

We used 2-year-old seedlings of the Japanese larch (Larix kaempferi) and Dahurian larch (Larix gmelinii var. japonica), and 3-year-old cuttings of the hybrid larch $\mathrm{F}_{1}$ (hereafter $\mathrm{F}_{1}$, Larix gmelinii var. japonica $\mathrm{x}$ L. kaempferi). The chloroplast DNA and mitochondrial DNA of Larix species indicate paternity of the Japanese larch and maternity of the Dahurian larch, respectively (Szmidt et al., 1987). Three-year-old specimens of $F_{1}$ were used for practical reasons relating to the Hokkaido Regional Government. The basal diameter of the stem and the height at the start of the experiment were 5.1 $\mathrm{mm}$ and $30 \mathrm{~cm}$ for the Japanese larch, $5.0 \mathrm{~mm}$ and 22 $\mathrm{cm}$ for the Dahurian larch, and $8.5 \mathrm{~mm}$ and $52 \mathrm{~cm}$ for $\mathrm{F}_{1}$. Prior to bud breaking, we planted these seedlings and cuttings in 7 liter pots filled with $1: 1(\mathrm{v} / \mathrm{v})$ mixture of Kanuma pumice soil and clay soil. $200 \mathrm{~mL}$ of liquid fertilizer $(\mathrm{N}: \mathrm{P}: \mathrm{K}=6: 10: 5$, Hyponex, Ohio, USA), diluted 500-fold, was supplied to all potted soils at 2weeks interval, for a total nitrogen $(\mathrm{N})$ application of $192 \mathrm{mg} \mathrm{N}$ per pot. Watering with tap water was carried out at 3-7 day intervals to prevent desiccation.

\section{2 Treatments}

We ran an open-top chamber (OTC) experiment from July to October with $\left[\mathrm{O}_{3}\right]$ (60 ppb: 7 hrs, 10:00-17:00), $\left[\mathrm{CO}_{2}\right]$ (600 ppm: during daytime) and their combination. We targeted the long-shoot needles because most needles of seedlings are long-shoot needles and in central Hokkaido begin to develop usually in late June, and to mature from early September (Kitaoka et al.,
2000). Inlet air was cleaned by a charcoal filter. The target $\left[\mathrm{O}_{3}\right]$ was the same concentration with environmental standard value for the photochemical oxidant in Japan, and similar or higher $\left[\mathrm{O}_{3}\right]$ has often been observed in many regions, including forested areas in Japan (Izuta, 2006). The chosen $\left[\mathrm{CO}_{2}\right]$ of $600 \mathrm{ppm}$ is predicted to be attained around the year 2060 (IPCC, 2007). The 16 OTCs $(1.2 \mathrm{~m} \times 1.2 \mathrm{~m} \times 1.2 \mathrm{~m}$ high $)$ were set in the experimental nursery of the Field Science Center for the Northern Biosphere of Hokkaido University $\left(43^{\circ} 06^{\prime} \mathrm{N}, 141^{\circ} 20^{\prime} \mathrm{E}, 15 \mathrm{~m}\right.$ a.s.l.). The OTCs were replicated four times for each gas treatment. Each OTC had two seedlings of each larch species.

\section{3 Growth Measurements}

The height and diameter of the seedlings were measured at the beginning and end (mid October) of the experiment, to determine growth. At the end of the experiment, all seedlings were harvested and were separated into each organ (i.e. stem, needle and root). The samples were oven-dried at $70^{\circ} \mathrm{C}$ for at least one week and then weighed. The T/R (Top/ Root) ratio was calculated as the dry mass ratio of above-ground to root.

\section{4 Gas Exchange Measurements}

In the middle of September, the gas exchange rates of mature needles were measured using an open gas exchange system (LI-6400, Li-Cor Inc., Lincoln, NE, USA), as specified in Watanabe et al. (2011). One or two seedlings per treatment-chamber combination were selected randomly for measurement. We determined the net photosynthetic rate $\left(A_{\text {growth }}\right)$ and the stomatal conductance $\left(G_{\mathrm{s}}\right)$ for water vapor at the chosen values of $\left[\mathrm{CO}_{2}\right]$, i.e., $380 \mathrm{ppm}$ for the ambient treatment and $600 \mathrm{ppm}$ for the elevated treatment. We calculated the net photosynthetic rate at $1700 \mu \mathrm{mol} \mathrm{mol}^{-1}$ ( $A_{\max }$, indicating maximum rate of ribulose-1,5-bisphosphate regeneration), the maximum rate of carboxylation $\left(V_{\mathrm{cmax}}\right)$ and the maximum rate of electron transport $\left(J_{\max }\right)$ from the intercellular $\mathrm{CO}_{2}$ concentration-response curve of the net photosynthetic rate (Long and Bernacchi, 2003; Farquhar et al., 1980). After measurement of the gas exchange rate, the needles were collected to determine the projected needle area as measured by an image scanner. The collected needles were dried in an oven at $70^{\circ} \mathrm{C}$ for at least one week and then weighed. The leaf mass per unit area (LMA) of needles was calculated as the ratio of dry mass to the area of the needles. Needle $\mathrm{N}$ and $\mathrm{C}$ concentrations were determined by a NC analyzer (Sumica-Shimadzu NC-900, Kyoto, Japan). We calculated the ratio of $A_{\text {growth }}$ to the N content as the photosynthetic $\mathrm{N}$ use efficiency (PNUE).

\section{5 Statistics}

Statistical analyses were performed using R software, 
version 2.8.1. Two-way analysis of variance (ANOVA) was used to test the effects of $\mathrm{O}_{3}$ and elevated $\left[\mathrm{CO}_{2}\right]$. In each analysis, a chamber was nested within each gas treatment and added as a random effect to the model. The reduced major axis regression method was used to analyze the relationship between pairs of variables.
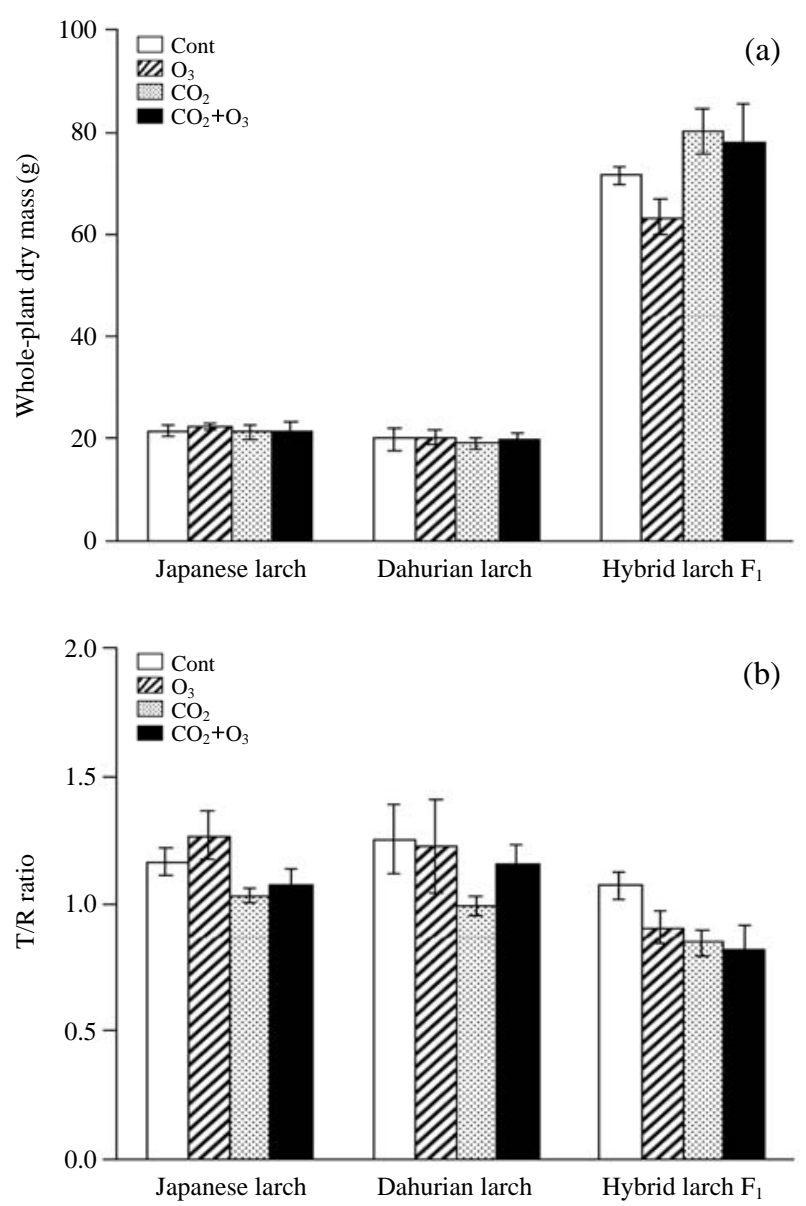

$\mathrm{P}$ value for two-way ANOVA

\begin{tabular}{lccc}
\hline & $\mathrm{O}_{3}$ & $\mathrm{CO}_{2}$ & $\mathrm{CO}_{2} \times \mathrm{O}_{3}$ \\
\hline Whole-plant dry mass & & & \\
Japanese larch & 0.753 & 0.651 & 0.770 \\
Dahurian larch & 0.806 & 0.772 & 0.910 \\
Hybrid larch $\mathrm{F}_{1}$ & 0.277 & 0.027 & 0.555 \\
T/R ratio & & & \\
Japanese larch & 0.184 & 0.006 & 0.531 \\
Dahurian larch & 0.555 & 0.155 & 0.397 \\
Hybrid larch $\mathrm{F}_{1}$ & 0.177 & 0.038 & 0.306 \\
\hline
\end{tabular}

Fig. 1. Effects of elevated $\left[\mathrm{O}_{3}\right]$ and/or $\left[\mathrm{CO}_{2}\right]$ on the wholeplant dry mass and Top-root dry mass ratio ( $\mathrm{T} / \mathrm{R}$ ratio) of three larch species. Each value is the mean of 8 determinations; the error bar shows the standard error. Cont: $\mathrm{O}_{3}$ free ambient air, $\mathrm{O}_{3}: 60 \mathrm{ppb} \mathrm{O}, \mathrm{CO}_{2}: 600 \mathrm{ppm} \mathrm{CO}_{2}$, The explanation is the same for the following figures.

\section{RESULTS}

\section{1 Biomass and Allocation (T/R)}

No significant effect of elevated $\left[\mathrm{O}_{3}\right]$ and/or elevated $\left[\mathrm{CO}_{2}\right]$ was found for the whole-plant dry mass of Japanese and Dahurian larch seedlings (Fig. 1a). Elevated $\left[\mathrm{O}_{3}\right]$ tended to reduce the whole-plant dry mass of $\mathrm{F}_{1}$. On the other hand, whole-plant dry mass of $\mathrm{F}_{1}$ grown at high $\left[\mathrm{CO}_{2}\right]$ was significantly larger than at ambient
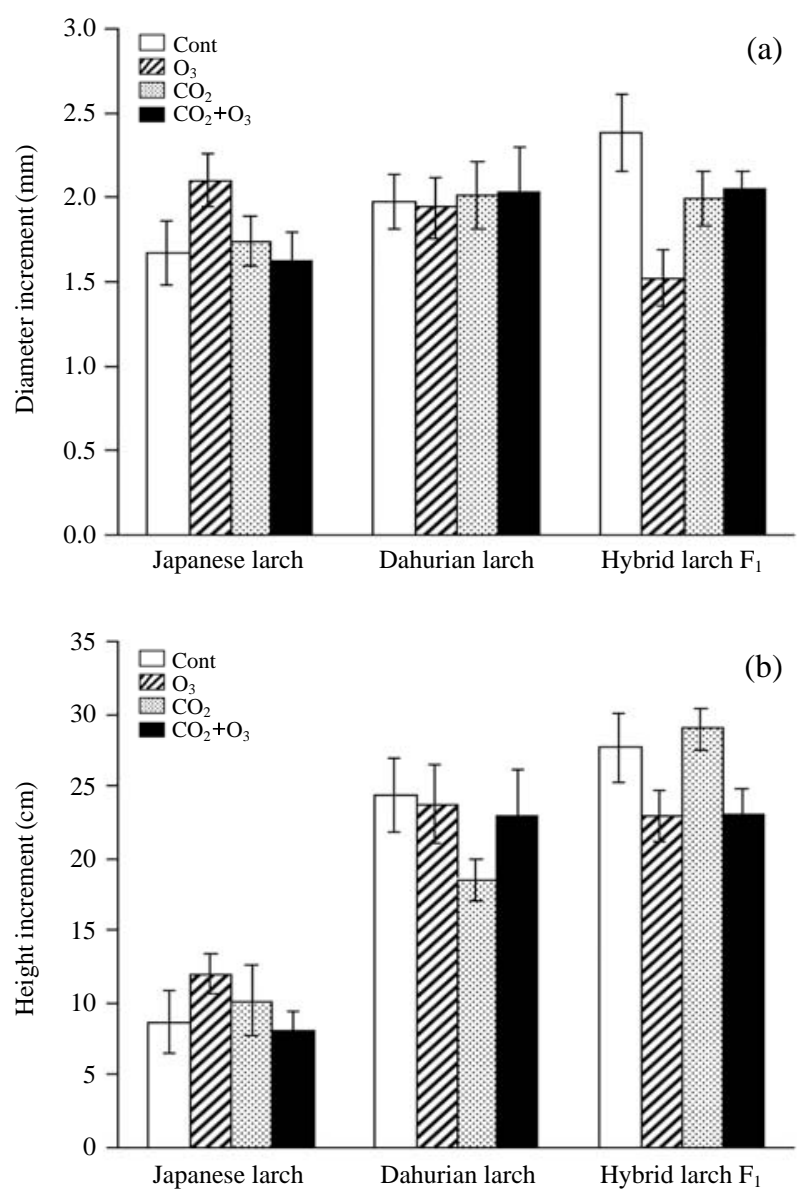

$\mathrm{P}$ value for two-way ANOVA

\begin{tabular}{lccc}
\hline & $\mathrm{O}_{3}$ & $\mathrm{CO}_{2}$ & $\mathrm{CO}_{2} \times \mathrm{O}_{3}$ \\
\hline Diameter increments & & & \\
Japanese larch & 0.322 & 0.189 & 0.086 \\
Dahurian larch & 0.686 & 0.853 & 0.609 \\
Hybrid larch $\mathrm{F}_{1}$ & 0.013 & 0.637 & 0.006 \\
Height increment & & & \\
Japanese larch & 0.676 & 0.473 & 0.116 \\
Dahurian larch & 0.259 & 0.098 & 0.188 \\
Hybrid larch $\mathrm{F}_{1}$ & 0.012 & 0.696 & 0.769 \\
\hline
\end{tabular}

Fig. 2. Stem basal diameter and height increments of three kinds of larch under elevated $\left[\mathrm{O}_{3}\right]$ and/or $\left[\mathrm{CO}_{2}\right]$, See legend for Fig. 1. 

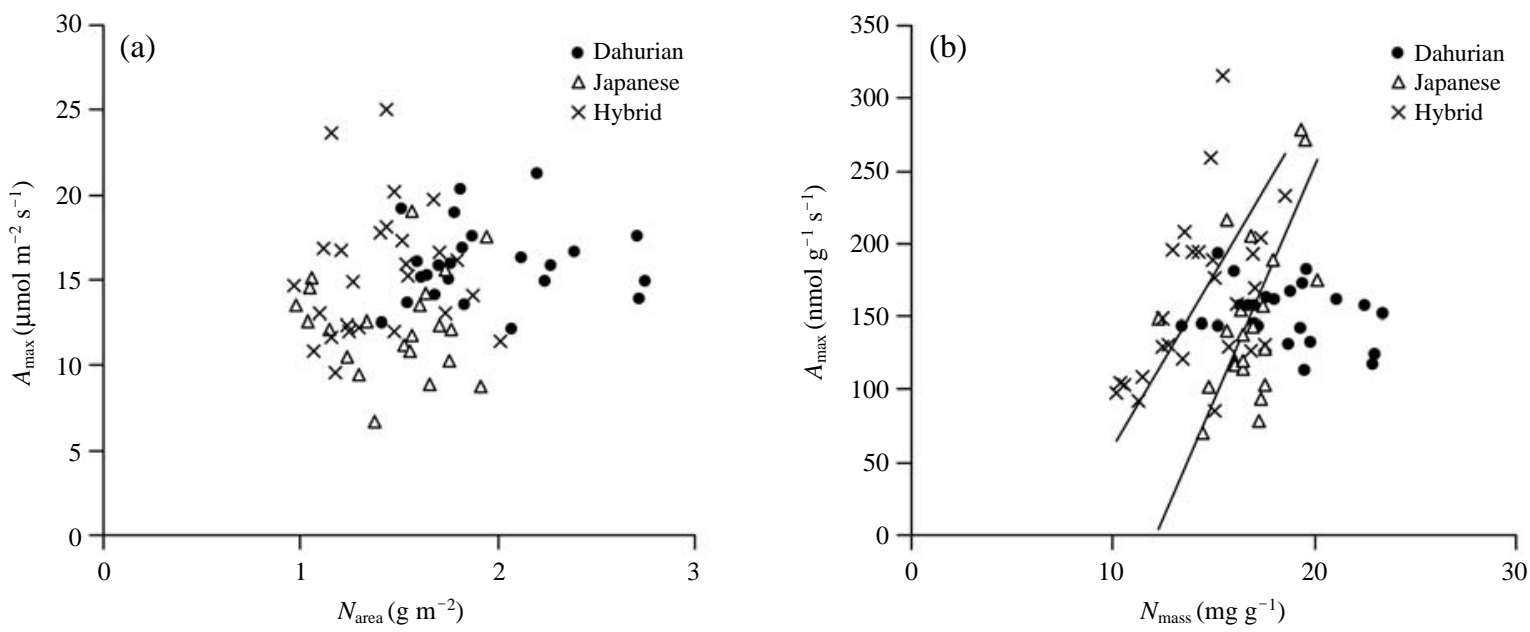

Fig. 3. Relationship between area-based (left) and mass-based (right) $A_{\max }$ and $\mathrm{N}$ in three larch species. $A_{\max }$ : net photosynthetic rate at $\mathrm{CO}_{2}$ and light saturation. The regression lines are obtained using the reduced major axis regression method $(\mathrm{y}=32.2 \mathrm{x}-$ $390.0, R^{2}=0.24^{*}$, for Japanese larch; $\mathrm{y}=23.6 \mathrm{x}-174.8, R^{2}=0.24^{*}$, for $\mathrm{F}_{1}$ ). There was no significance in the regression line for dahurian $\operatorname{larch}\left(R^{2}=0.09\right)$.

Table 1. Needle photosynthetic parameters of three kinds of larch treated with elevated $\left[\mathrm{O}_{3}\right]$ and/or $\left[\mathrm{CO}_{2}\right]$.

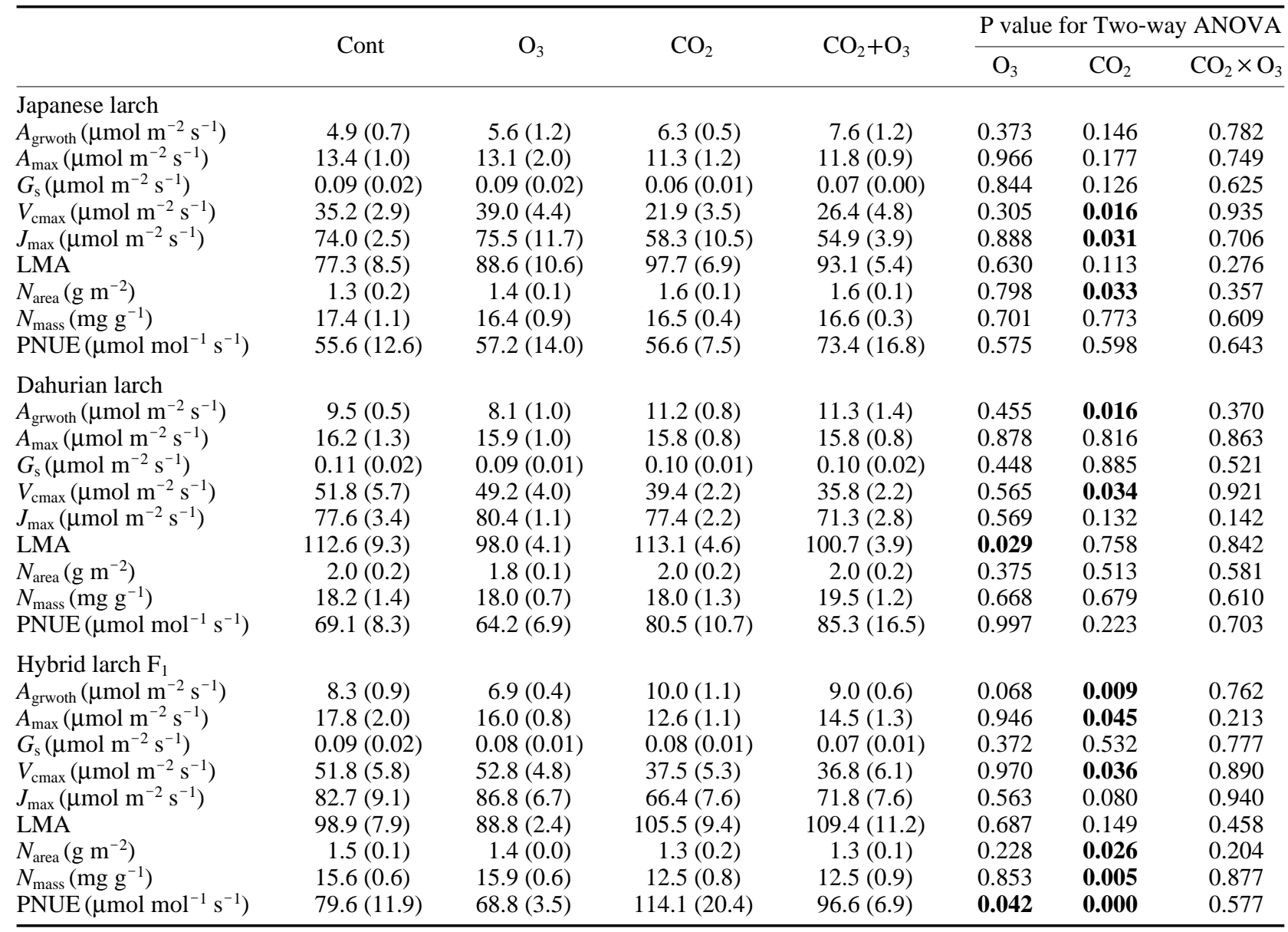

$A_{\text {growth }}$, net photosynthetic rate at growth $\mathrm{CO}_{2}$ concentration; $A_{\max }$, net photosynthetic rate at $\mathrm{CO}_{2}$ saturation; $G_{\mathrm{s}}$, stomatal conductance to water vapor; $V_{\mathrm{cmax}}$, maximum rate of carboxylation; $J_{\max }$, maximum rate of electron transport; LMA, leaf mass per area; $N_{\text {area }}$, nitrogen content per unit needle area; PNUE. photosynthetic nitrogen use efficiency. Each value is the mean of 8 measurements; the standard error is shown in parentheses. 
$\left[\mathrm{CO}_{2}\right](\mathrm{P}<0.05)$. There was no significant interaction effect of elevated $\left[\mathrm{O}_{3}\right]$ and $\left[\mathrm{CO}_{2}\right]$ on the whole-plant dry mass of $F_{1}$. The T/R of the Japanese larch and $F_{1}$ was significantly reduced at elevated $\left[\mathrm{CO}_{2}\right]$ relative to ambient $\left[\mathrm{CO}_{2}\right]$ (Fig. 1b). No increase of $\mathrm{T} / \mathrm{R}$ was found in seedlings of any species treated with $\left[\mathrm{O}_{3}\right]$; T/R for $\mathrm{F}_{1}$ tended to be small at high $\left[\mathrm{O}_{3}\right](\mathrm{P}=0.177)$. The needle biomass of Dahurian and Japanese larches was fairly similar in all treatments, but for $F_{1}$ it was significantly lower at high $\left[\mathrm{O}_{3}\right]$ (data not shown).

The height increment, and the diameter increment at the bottom of the stem of $F_{1}$ was significantly less under elevated $\left[\mathrm{O}_{3}\right]$, whereas no significant effect of $\mathrm{O}_{3}$ was found in the Japanese or Dahurian larches (Fig. 2). We found a significant interaction between elevated $\left[\mathrm{O}_{3}\right]$ and $\left[\mathrm{CO}_{2}\right]$ influencing the diameter increment. Although elevated $\left[\mathrm{O}_{3}\right]$ clearly impairs the stem diameter increment under ambient $\left[\mathrm{CO}_{2}\right]$, no such effect was observed under high $\left[\mathrm{CO}_{2}\right]$.

\section{2 Photosynthetic Parameters}

The exposure to $\mathrm{O}_{3}$ significantly reduced the LMA of the Dahurian larch and the PNUE of $\mathrm{F}_{1}$, and marginally decreased $A_{\text {growth }}$ for $\mathrm{F}_{1}$ (Table 1 ). Elevated $\left[\mathrm{CO}_{2}\right]$ induced significant increases were found in $N_{\text {area }}$ of the Japanese larch, $A_{\text {growth }}$ of the Dahurian larch and $A_{\text {growth }}$ and PNUE of $F_{1}$. Significant decreases were detected in $V_{\text {cmax }}$ of all species, and in $A_{\max }, N_{\text {area }}$ and $N_{\text {mass }}$ of $\mathrm{F}_{1}$, and marginally in $J_{\max }$ of $\mathrm{F}_{1}$. There was no significant interaction between elevated $\left[\mathrm{O}_{3}\right]$ and $\left[\mathrm{CO}_{2}\right]$ influencing the value of any photosynthetic parameters.

No significant correlation was found between areabased $A_{\max }$ and $N_{\text {area }}$ in needles (Fig. 3a). On the other hand, there was a positive correlation between the massbased $A_{\max }$ and $N_{\text {mass }}$ in needles of the Japanese larch and $\mathrm{F}_{1}$ (Fig. 3b). No clear trend was found in the Dahurian larch, however.

\section{DISCUSSION}

No significant effect of elevated $\left[\mathrm{O}_{3}\right]$ and/or elevated $\left[\mathrm{CO}_{2}\right]$ was found for the whole-plant dry mass of Japanese and Dahurian larch seedlings, while $F_{1}$ treated with high $\left[\mathrm{CO}_{2}\right]$ had high dry mass (Fig. 1). The needle biomass of $\mathrm{F}_{1}$ was lower at high $\left[\mathrm{O}_{3}\right]$ than at low $\left[\mathrm{O}_{3}\right]$. The trend of depression in the whole-plant biomass of $\mathrm{F}_{1}$ at high $\left[\mathrm{O}_{3}\right]$ may be due to a decrease in the needle biomass. Furthermore, the stem diameter increment and height increment of $F_{1}$ were significantly impaired by elevated $\left[\mathrm{O}_{3}\right]$ (Fig. 2). The $\mathrm{O}_{3}$-induced growth reduction found in $\mathrm{F}_{1}$ might be due to the lower $A_{\text {growth}}$, although it was marginally significant (Table 1 ). The extent of the $\mathrm{O}_{3}$ effects on plant greatly depends on amounts of $\mathrm{O}_{3}$ uptake through stomata and detoxification for $\mathrm{O}_{3}$ and reactive oxygen species (ROS) derived from $\mathrm{O}_{3}$ within foliage (Fuhrer and Booker, 2003). We considered the uptakes of $\mathrm{O}_{3}$ were similar among the three species because of no difference of $G_{\mathrm{s}}$ (Table 1 ). There is a possibility of lower detoxification capacity for $\mathrm{O}_{3}$ and/or ROS in $\mathrm{F}_{1}$. We may be able to conclude this as a weakness in $\mathrm{F}_{1}$ against $\mathrm{O}_{3}$.

We did not observe a significant decrease in $\mathrm{N}$ content in the needles of larches exposed to $\mathrm{O}_{3}$. Yamaguchi et al. (2007) reported a reduction in the net photosynthetic rate of leaves of the Siebold's beech (Fagus crenata) due to an $\mathrm{O}_{3}$-induced reduction in PNUE. Furthermore, their subsequent study revealed a reduction in the concentration ratio of total soluble protein (of which the main component is Rubisco, ribulose-1,5bisphosphate carboxylase/oxygenase, a key enzyme for photosynthesis), to the total $\mathrm{N}$ in leaves exposed to $\mathrm{O}_{3}$. In the present study (Table 1), the PNUE under high $\left[\mathrm{O}_{3}\right]$ was significantly lower than that under low $\left[\mathrm{O}_{3}\right]$. We therefore believe that the decrease in photosynthetic $\mathrm{N}$ utilization leads to the decrease in $A_{\text {growth }}$ of $\mathrm{F}_{1}$.

Plants deploy defense and repair processes against $\mathrm{O}_{3}$ damage which require photosynthetic assimilates (Fuhrer and Booker, 2003). This diversion of assimilates to defense and/or repair processes may result in the growth reduction of needles of $\mathrm{F}_{1}$. The $\mathrm{O}_{3}$-induced increase of antioxidant and phenolic compounds were reported from several researches (Omasa et al., 2005; Watanabe et al., 2005; Wiser et al., 1993). Or $\mathrm{O}_{3}$ may simply reduce needle biomass via reduction of photosynthetic function (e.g. Matyssek et al., 1993).

A positive correlation between foliar $\mathrm{N}$ and $A_{\max }$ is observed in many species (e.g. Schulze et al., 2005; Larcher, 2003) because large part of foliar $\mathrm{N}$ is used for photosynthetic function such as Rubisco and chlorophyll (Kitaoka and Koike, 2004). In Japanese larch and $\mathrm{F}_{1}$, in fact, we found positive correlation between mass-basis $\mathrm{N}$ and $A_{\max }$ (Fig. 3). However no such correlation was found for the Dahurian larch. This may be related to the small LMA value at elevated $\left[\mathrm{O}_{3}\right]$, suggesting that biomass production at high $\left[\mathrm{O}_{3}\right]$ was restricted.

Photosynthetic acclimation to high $\left[\mathrm{CO}_{2}\right]$ took place, as indicated by the reduction of $V_{\mathrm{cmax}}, J_{\max }$ and/or $A_{\max }$ (Table 1). This homeostatic adjustment occurs in many species (Watanabe et al., 2011; Koike et al., 1996; Tissue and Oechel, 1987). Biomass production was initially accelerated by high $\left[\mathrm{CO}_{2}\right]$, but the effect usually ceased with deficiency of nutrients, dilution of $\mathrm{N}$ with rapid growth and depression of Rubisco activity (Watanabe et al., 2011; Larcher, 2003). For fast growing species, including larch, the pot size may restrict 
the growth of below-ground biomass at elevated $\left[\mathrm{CO}_{2}\right]$, independent of $\left[\mathrm{O}_{3}\right]$ (Koike et al., 1996). In setting up new plantations with $F_{1}$ we should pay attention to the source-sink relation, i.e. the T/R ratio, as for an indicator of survival of plants under increasing $\left[\mathrm{O}_{3}\right]$.

In the present study, the effect of elevated $\left[\mathrm{CO}_{2}\right]$ in compensating for the $\mathrm{O}_{3}$-induced reduction in growth of the stem basal-diameter of $F_{1}$ was clear, but there was no similar trend in the other growth and photosynthetic parameters, and the other species. The effect of elevated $\left[\mathrm{CO}_{2}\right]$ on the height-growth reduction at high $\left[\mathrm{O}_{3}\right]$ was not the same for aspen and birch (Karnosky et al., 2007). Moreover, trees have different sensitivity to $\left[\mathrm{O}_{3}\right]$ and the sensitivity may change with growth stage (Kolb and Matyssek, 2001). In seedlings of the Siebold's beech, growth at high $\left[\mathrm{O}_{3}\right]$ was dramatically accelerated with elevated $\left[\mathrm{CO}_{2}\right]$ via the production of extra secondary flush leaves (Watanabe et al., 2010). Although down-regulation by elevated $\left[\mathrm{CO}_{2}\right]$ was found in our three larches, the net photosynthetic rate measured at the cultivated $\left[\mathrm{CO}_{2}\right]$ was greater in seedlings of the Dahurian larch and $\mathrm{F}_{1}$ grown at elevated $\left[\mathrm{CO}_{2}\right]$. In $\mathrm{F}_{1}$, the surplus photosynthates at high $\left[\mathrm{CO}_{2}\right]$ may efficiently be allocated to defense against $\mathrm{O}_{3}$ or to repair parts of plant organs damaged by $\mathrm{O}_{3}$ (e.g., Dizengremel et al., 2008; Fuhrer and Booker, 2003).

In conclusion, a negative effect of elevated $\left[\mathrm{O}_{3}\right]$ was observed mainly in $\mathrm{F}_{1}$. This is a concern for future afforestation with $\mathrm{F}_{1}$. The effect of high $\left[\mathrm{CO}_{2}\right]$ in compensating for the reduction of stem diameter growth of $\mathrm{F}_{1}$ at high $\left[\mathrm{O}_{3}\right]$ is an important insight. Further detailed study of the mechanisms of these effects in the hybrid larch $F_{1}$ should clarify its suitability for future afforestation projects in an atmosphere containing elevated $\left[\mathrm{O}_{3}\right]$ and $\left[\mathrm{CO}_{2}\right]$.

\section{ACKNOWLEDGEMENT}

We thank Ms. M. Tonooka and Prof. Y. Takeuchi (Tokai University) for their kind and intensive cooperation in making the measurements. Thanks are also due for financial support by the Environment Research \& Technology Development Fund of Japan (B-1105) and a Grant-in-aid from the Japanese Society for Promotion of Science for Type B (23380078), Research Fellowship for young scientists (20-1143) and Young Scientists B (24710027 and 24780239).

\section{REFERENCES}

Dizengremel, P., Le Thiec, D., Bagard, M., Jolivet, Y. (2008) Ozone risk assessment for plants: Central role of metabolism-dependent changes in reducing power. Environmental Pollution 156, 11-15.

Farquhar, G.D., von Caemmerer, S., Berry, J.A. (1980) A biochemical model of photosynthetic $\mathrm{CO}_{2}$ assimilation in leaves of C3 species. Planta 149, 78-90.

Fuhrer, J., Booker, F. (2003) Ecological issues related to ozone: agricultural issues. Environment International 29, 141-154.

IGBP (1998) The terrestrial carbon cycle: Implications for the Kyoto Protocol. Science 280, 1393-1394.

IPCC (2007) International Conference on Parallel Processing. Cambridge University Press, U.K.

Izuta, T. (2006) Plants and environmental stresses, Corona Publisher, Tokyo, in Japanese.

Karnosky, D.F., Percy, K.E., Chapperka, A.H., Simpson, C., Pikkarainen, J. (2005) Air Pollution, Global Change and Forests in new Millennium. Elsevier. USA.

Karnosky, D.F., Werner, H., Holopainen, T., Percy, K., Oksanen, T., Oksanen, E., Heerdt, C., Fabian, P., Nagy, J., Heilman, W., Cox, R., Nelson, N., Matyssek, R. (2007) Free-air exposure systems to scale up ozone research to mature trees. Plant Biology 9, 181-190.

Kita, K. (2011) Hybridization of genus Larix for moderating global warming. In Forest In Hokkaido (Boreal Forest Research Eds), Hokkaido News Paper Press, Sapporo, pp. 249-253. (in Japanese)

Kitaoka, S., Koike, T. (2004) Invasion of broad-leaf tree species into a larch plantation: seasonal light environment, photosynthesis and nitrogen allocation. Physiologia Plantarum 121, 604-611.

Kitaoka, S., Mori, S., Matsuura, Y., Abaimov, A.P., Sugishita, Y., Satoh, F., Sasa, K., Koike, T. (2000) Comparison between the photosynthetic characteristics of larch species grown in northern Japan and central Siberia. Proceedings of the Joint Siberia Permafrost Studies $8,49-54$.

Koike, T. (2009) A trial of revegetation practices with larch species under changing environment. Landscape \& Ecological Engineering 5, 97-98.

Koike, T., Lei, T.T., Maximov, T.C., Tabuchi, R., Takahashi, K., Ivanov, B.I. (1996) Comparison of the photosynthetic capacity of Siberian and Japanese birch seedlings grown in elevated $\mathrm{CO}_{2}$ and temperature. Tree Physiology 16, 381-385.

Kolb, T.E., Matyssek, R. (2001) Limitations and perspectives about scaling ozone impacts in trees. Environmental Pollution 115, 373-393.

Körner Ch, Asshoff, R., Bignucolo, O., Hättenschwiler, S., Keel, S.G., Peláez-Riedl, S., Pepin, S., Siegwolf, R.T.W., Zotz, G. (2005) Carbon flux and growth in mature deciduous forest trees exposed to elevated $\mathrm{CO}_{2}$. Science 309, 1360-1362.

Kume, A., Numata, S., Watanabe, K., Honoki, H., Nakajima, H., Ishida, M. (2009) Influence of air pollution on the mountain forests along the Tateyama-Kurobe Alpine route. Ecological Research 24, 821-830.

Kuromaru, M., Kita, K., Uchiyama, S., Fujimoto, T. (2011) Development of "clean larch" with high $\mathrm{CO}_{2}$ storage 
capacity and the establishment of propagation method. http://www.fri.hro.or.jp/news/hyosyo/hyosyo10.html.

Larcher, W. (2003) Physiological plant ecology. Springer$\mathrm{V}$.

Long, S.P., Bernacchi, C.J. (2003) Gas exchange measurements, what can they tell us about the underlying limitations to photosynthesis? Procedures and sources of error. Journal of Experimental Botany 54, 2393-2401.

Matsumura, H., Mikami, C., Sakai, Y., Murayama, K., Izuta, T., Yenekura, T., Miwa, M., Kohno, Y. (2005) Impacts of elevated $\mathrm{O}_{3}$ and/or $\mathrm{CO}_{2}$ on growth of Betula platyphylla, Betula ermanii, Fagus crenata, Pinus densiflora and Cryptomeria japonica seedlings. Journal of Agricultural Meteorology 60, 1121-1124.

Matyssek, R., Keller, Th., Koike, T. (1993) Branch growth and leaf gas exchange of Populus tremula exposed to low ozone concentration through out two growing seasons. Environmental Pollution 79, 1-7.

Ohara, T. (2011) Why is the increase of tropospheric ozone concentration in mountain and island regions in Japan? Japanese Journal of Ecology 61, 77-81. (in Japanese)

Ohara, T., Akimoto, H., Kurokawa, J., Horii, N., Yamaji, K., Yan, X., Hatasaka, T. (2007) An Asian emission inventory of anthropogenic emission sources for the period 1980-2020. Atmospheric Chemistry and Physics 7, 4419-4444.

Omasa, K., Nouchi, I., De Kok, L.J. (2005) Plant responses to air pollution and global change, Springer-Verlang, Tokyo.

Paoletti, E., Grulke, N.E. (2005) Does living in elevated $\mathrm{CO}_{2}$ ameliorate tree response to ozone? A review on stomatal responses. Environmental Pollution 137, 483493.

Ryu, K., Watanabe, M., Shibata, H., Takagi, K., Nomura, M., Koike, T. (2009) Ecophysiological responses of the larch species in northern Japan to environmental changes as a base of afforestation. Landscape \& Ecological Engineering 5, 99-106.

Schulze, E.-D., Beck, E., Müller-Hohenstein, E. (2005) Plant Ecology. Springer-V. Berlin, Heidelberg, Germany.

Szmidt, A.E., Aldén, T., Hällgren J.-E. (1987) Paternal inheritance of chloroplast DNA in Larix. Plant Molecular Biology 9, 54-69.

Takeda, M., Aihara, K. (2007) Effects of ambient ozone concentrations on Beech (Fagus crenata) seedlings in the Tanzawa Mountains, Kanagawa Prefecture, Japan. Journal of Japanese Society for Atmospheric Environment 42, 107-117. (in Japanese with English summary)

Tissue, D.T., Oechel, W.C. (1987) Response of Eriophorum vaginalum to elevated $\mathrm{CO}_{2}$ and temperature in the Alaskan tussock tundra. Ecology 68, 401-410.

Watanabe, M., Umemoto-Yamaguchi, M., Koike, T., Izuta, T. (2010) Growth and photosynthetic response of Fagus crenata seedlings to ozone and/or elevated carbon dioxide. Landscape \& Ecological Engineering 6, 181-190.

Watanabe, M., Watanabe, Y., Kitaoka, S., Utsugi, H., Kita, K., Koike, T. (2011) Growth and photosynthetic traits of hybrid larch $\mathrm{F}_{1}$ (Larix gmelinii var. japonica $\times L$. kaempferi) under elevated $\mathrm{CO}_{2}$ concentration with low nutrient availability. Tree Physiology 31, 965-975.

Watanabe, M., Yonekura, T., Honda, Y., Yoshidome, M., Izuta, T. (2005) Effects of ozone and soil water stress, singly and in combination, on leaf antioxidative systems of Fagus crenata seedlings. Journal of Agricultural Meteorology 60, 1105-1108.

Wiser, G. (1993) Evaluation of the impact of ozone on conifers in the Alps: A case study on spruce, pine and larch in the Austrian Alps. Phyton 39, 241-252.

Yamaguchi, M., Watanabe, M., Iwasaki, M., Tabe, C., Matsumura, H., Kohno, Y., Izuta, T. (2007) Growth and photosynthetic responses of Fagus crenata seedlings to $\mathrm{O}_{3}$ under different nitrogen loads. Trees 6, 707-718.

Yonekura, T., Honda, Y., Oksanen, E., Yoshidome, M., Watanabe, M., Funada, R., Koike, T., Izuta, T. (2001) The influences of ozone and soil water stress, singly and in combination, on leaf gas exchange rates, leaf ultrastructural characteristics and annual ring width of Fagus crenata seedlings. Journal of Japan Society for Atmospheric Environment 36, 333-351.

(Received 30 November 2011, revised 21 February 2012, accepted 27 February 2012) 